\title{
Fractographic analysis of two fractured removable partial denture metal
}

\section{frameworks}

\author{
Análise fractográfica de duas estruturas metálicas de próteses parciais removíveis fraturadas \\ Análisis fractográfico de dos estructuras metálicas de prótesis parciales removibles fracturadas
}

Received: 07/18/2021 | Reviewed: 07/25/2021 | Accept: 07/28/2021 | Published: 08/04/2021

Jussara da Silva Barbosa

ORCID: https://orcid.org/0000-0001-6123-5266

Universidade Estadual da Paraíba, Brasil

E-mail: barbosajsara@gmail.com

Elisa Diniz de Lima

ORCID: https://orcid.org/0000-0003-2840-7825

Universidade Estadual da Paraíba, Brasil

E-mail: elisadinizdelima@gmail.com

João Baptista Costa Agra de Melo

ORCID: https://orcid.org/0000-0002-1577-8590

Universidade Federal de Campina Grande, Brasil

E-mail: joao.baptista@ufcg.edu.br

André Ulisses Dantas Batista

ORCID: https://orcid.org/0000-0003-1593-0174

Universidade Federal da Paraíba, Brasil

E-mail: andreulisses@yahoo.com.br

João Paulo Silva Neto

ORCID: https://orcid.org/0000-0002-3140-2403 Universidade Estadual da Paraíba, Brasil

E-mail: joaopaulosneto@gmail.com

Herrison Félix Valeriano da Silva

ORCID: https://orcid.org/0000-0001-6714-3151 Universidade Federal da Paraíba, Brasil E-mail: Herrison.felix.vds@gmail.com

Thauany Vasconcelos Soares da Silva ORCID: https://orcid.org/0000-0002-6831-9224 Universidade Federal da Paraíba, Brasil E-mail: vasconcelosthauany@gmail.com

Matheus Gonçalves de Assunção ORCID: https://orcid.org/0000-0002-7230-1721

Universidade Estadual de Campinas, Brasil E-mail: M235966@dac.unicamp.br

Ana Maira Pereira Baggio

ORCID: https://orcid.org/0000-0002-9474-5091

Universidade Estadual de Campinas, Brasil E-mail: anamairabaggio@gmail.com

José Renato Cavalcanti Queiroz

ORCID: https://orcid.org/0000-0001-8573-0288 Universidade Estadual da Paraíba, Brasil

E-mail: joserenatocq@ hotmail.com

\begin{abstract}
This study aimed to analyze two cases of fracture of the metal framework of Co-Cr-based removable partial dentures, using fractography to identify a true cause of these failures. The first case concerned the coupling between the smaller and larger connectors; the patient brought his fractured removable partial dentures to the clinic. The second case referred to a larger connector; structure of the patient fractured during the test. For failure analysis, images of two fractured metal frameworks were taken by scanning electron microscopy to identify the origin of the fracture and to determine the mechanisms involved in the process. Subsequently, energy dispersive X-ray spectroscopy was used for elemental chemical mapping of the fracture interface. The fractography indicated material fatigue as a possible cause in the first case and an error in the casting process in the second. The energy dispersive Xray spectroscopy test, performed in the specimen of case B, showed predominant and characteristic peaks for Co and $\mathrm{Cr}$, with a higher concentration of chromium. The fractures identified were associated with inclusions and with material fatigue and a number important characteristics were evidenced by the technique.
\end{abstract}

Keywords: Chromium alloys; Cobalt; Removable partial denture; Scanning electron microscopy. 


\section{Resumo}

Este estudo teve como objetivo analisar dois casos de fratura da estrutura metálica de próteses parciais removíveis à base de $\mathrm{Co}-\mathrm{Cr}$, utilizando a fractografia para identificar a verdadeira causa dessas falhas. O primeiro caso dizia respeito ao acoplamento entre os conectores menores e maiores; o paciente trouxe suas próteses parciais removíveis fraturadas para a clínica. O segundo caso se referia a um conector maior; estrutura do paciente fraturada durante o teste. Para análise de falha, imagens de duas estruturas metálicas fraturadas foram obtidas por microscopia eletrônica de varredura para identificar a origem da fratura e determinar os mecanismos envolvidos no processo. Posteriormente, a espectroscopia de energia dispersiva de raios-X foi usada para mapeamento químico elementar da interface de fratura. A fractografia indicou fadiga do material como possível causa no primeiro caso e erro no processo de fundição no segundo. O teste de espectroscopia de energia dispersiva de raios-X, realizado no corpo de prova do caso B, apresentou picos predominantes e característicos para Co e $\mathrm{Cr}$, com maior concentração de cromo. As fraturas identificadas foram associadas a inclusões e à fadiga do material e uma série de características importantes foram evidenciadas pela técnica.

Palavras-chave: Ligas de cromo; Cobalto; Prótese parcial removível; Microscopia eletrônica de varredura.

\section{Resumen}

Este estudio tuvo como objetivo analizar dos casos de fractura de la estructura metálica de prótesis parciales removibles a base de Co-Cr, utilizando la fractografía para identificar una verdadera causa de estas fallas. El primer caso se refería al acoplamiento entre los conectores más pequeños y más grandes; el paciente trajo a la clínica sus dentaduras postizas parciales removibles fracturadas. El segundo caso se refería a un conector más grande; estructura del paciente fracturada durante la prueba. Para el análisis de fallas, se tomaron imágenes de dos estructuras metálicas fracturadas mediante microscopía electrónica de barrido para identificar el origen de la fractura y determinar los mecanismos involucrados en el proceso. Posteriormente, se utilizó espectroscopía de rayos $\mathrm{X}$ de dispersión de energía para el mapeo químico elemental de la interfaz de la fractura. La fractografía indicó la fatiga del material como posible causa en el primer caso y un error en el proceso de fundición en el segundo. La prueba de espectroscopia de rayos $\mathrm{X}$ de energía dispersiva, realizada en la muestra del caso $\mathrm{B}$, mostró picos predominantes y característicos para $\mathrm{Co}$ y $\mathrm{Cr}$, con una mayor concentración de cromo. Las fracturas identificadas se asociaron con inclusiones y con la fatiga del material y la técnica evidenció una serie de características importantes.

Palabras clave: Aleaciones de cromo; Cobalto; Dentadura parcial removible; Microscopía electrónica de barrido.

\section{Introduction}

For years, the materials of choice for the manufacture of the metal framework of removable partial dentures (RPD) were the noble alloys, particularly those based on gold. Due to the high price of gold in the international market and the search to replace such alloys, from the 1930s onward, Erdle and Prange (1934), developed dental casting techniques for Co-Cr (cobalt-chrome-based) alloys to achieve the desirable physicochemical properties and techniques of prosthetic manufacturing device developed up to that time (Earnshaw,1958; Blackman,1991).

Co-Cr-based metal alloys exhibit properties that include good rigidity, low density and high modulus, which offer greater resistance to flexure in smaller structural dimensions, biocompatibility, low cost, discoloration resistance compared to gold alloy and easy laboratory handling (Carr, et al.,2011), considered similar or even superior to gold alloy (Paffenbarger, et al.1943).

Knowledge concerning the mechanical properties of the alloy and the casting technique facilitate the planning and fabrication of the metal components of RPDs, so they can perform their functions without undergoing plastic or fracture deformation, because even though they are rare, fracture events are one of the causes of failure of metal components of RPDs (Harcourt,1961; Bates,1965). Some authors have described examples of structural defects (voids, porosities and inclusions) that can cause failures in the RPD due to casting techniques, mechanical adjustments to cold, lack of user care in the placement and removal of the prosthesis and the poor architecture of the metal framework (Lewis,1978; Noort, et al.,1984). Other variables, including alloy selection and the processing of materials can also contribute to the incidence of structural failure (Earnshaw,1961). 
Fractography is the study and interpretation of fracture surface detail, which is useful in determining the nature of this process, providing valuable information regarding the analysis of a fracture, such as the mode and the point of crack initiation. Fractography has proven to be an excellent technique for visualizing typical characteristics of various defects in materials, such as porosity, inclusions, material overlaps and surface defects (Wouters, et al.,1997).

Micromechanical fractures manifest in several forms, including ductile, brittle and fatigue. Ductile fractures are characterized by severe plastic deformation preceding the fracture after substantial energy consumption, gradually and continuously (slow crack propagation), with the formation of wells (dimples) in the surface. In contrast, brittle fractures exhibit little or no plastic deformation before a sudden break occurs (rapid crack propagation) and they require less energy consumption, they show low tolerance for metallurgical discontinuities and may present lines or ridges on the surface (Carr, et al.,2011).

Fatigue is another form of failure that leads to fracture through the loss of mechanical properties of a material under low repetitive loads occurs in structures that are subject to dynamic stresses and swaying movements, occurring progressively with the formation and propagation of a crack, where this encounters structural and compositional imperfections. Fatigue fractures can also arise at points where high tensions concentrate, presenting macroscopic features on the surface of the fracture, known as 'beach marks'; the final fracture may show brittle and ductile characteristics (Carr, et al.,2011; Phillips, 1991).

The structure of a RPD may suffer fatigue fracture caused during the insertion and removal of the prosthesis. The term "fatigue" is used because this type of fracture typically occurs after a long period of repeated stresses or deformation cycles, as in the case of RPDs, showing distinctive characteristics on its surface (Craig, et al.,1993; Morris, et al.,1976).

In this context, it is crucial to analyze cases of fractures in metal components of RPDs to determine the possible types and causes of these failures. Fractography is an effective tool for identifying the causes of failures, providing important information based on the interpretation of details and the recognition of fracture patterns (Pang, et al., 2006)

The literature has few in-depth studies concerning the causes of fractures in metal frameworks of RPDs (Noort, et al.,1984; Ben-ur,1986). Therefore, this study aimed to analyze two cases of fracture of the metal framework of Co-Cr-based RPDs, using fractography to identify a true cause of these failures.

\section{Methodology}

This study is an account of cases where the fractography was performed on the metal frameworks of two patients, the first came from the Prosthodontics Clinic at the Federal University of Paraiba (UFPB) and the second from the Prosthesis Clinic of the State University of Paraiba (UEPB). The first case concerned the coupling between minor and major connectors; the patient brought his fractured RPD to the clinic. The second case concerned a major connector; the patient's metal framework fractured while being tested.

Case A: RPD previously fabricated by a commercial prosthesis laboratory that used Co-Cr alloys to make the lower metal frame, being used by the patient for 20 months. The patient presented with a totally edentulous upper jaw (full prosthesis user), while his lower arch was Kennedy Class III modification 1, rehabilitated with a RPD. The patient reported that the lower RPD was well suited and in use, but that after chewing hard food, he felt that the RPD had broken. Analysis of the prosthesis provided by the patient indicated that the fracture had occurred in the final post of the joining area between the upper and lower connector (in the mesial region of mandibular left second molar). The fracture was considered catastrophic due to the inability to continue using the RPD. 
Case B: New PPRs were produced by a commercial prosthetic laboratory for this patient, who also used Co-Cr alloys to make the metal frames of the prostheses. The patient's upper arch was Kennedy class III modification 1, while her lower arch was class II modification 3. Restorative procedures and a radiographic examination of the supporting teeth were performed for prosthetic purposes. The patient was submitted to the stages of RPDs preparation, but the lower metal framework fractured during tests.

\section{Failure analysis in sem and eds}

The fractured specimens were cut with carborundum disc, in low rotation, for facilitation of the tests, far from the fracture area. To clean the fracture, the pieces were washed in acetone and dried with mild air jets using a triple syringe (oilfree). Next, images of the specimens were taken by scanning electron microscope (SEM) to identify the source and possible types of fracture present at the interfaces, in order to generate hypotheses regarding possible causes of the fracture. Subsequently, energy dispersive X-ray spectroscopy (EDS) was performed to identify the presence and concentration of chemical elements at the fractured interface.

\section{Results and Discussion}

In Case A (Figures 1.1-1.4 and 2), the flutes between the minor and major connectors in the junction area are arranged to indicate the direction of propagation of the fracture from the region identified as the beginning of the failure (Figures 1.1 and 1.2). In two regions, the surface had a rough appearance created by microvoid coalescence, characterizing a ductile fracture or shear (Figure 1.3). However, in certain regions of the same piece, the surface showed lines or ribs, which is characteristic of a brittle fracture (Figure 1.4). Thus, the metal framework in Case A presented a mixed fracture.

Figure 1.1- Micrographs of the fatigue fracture area: (40x).

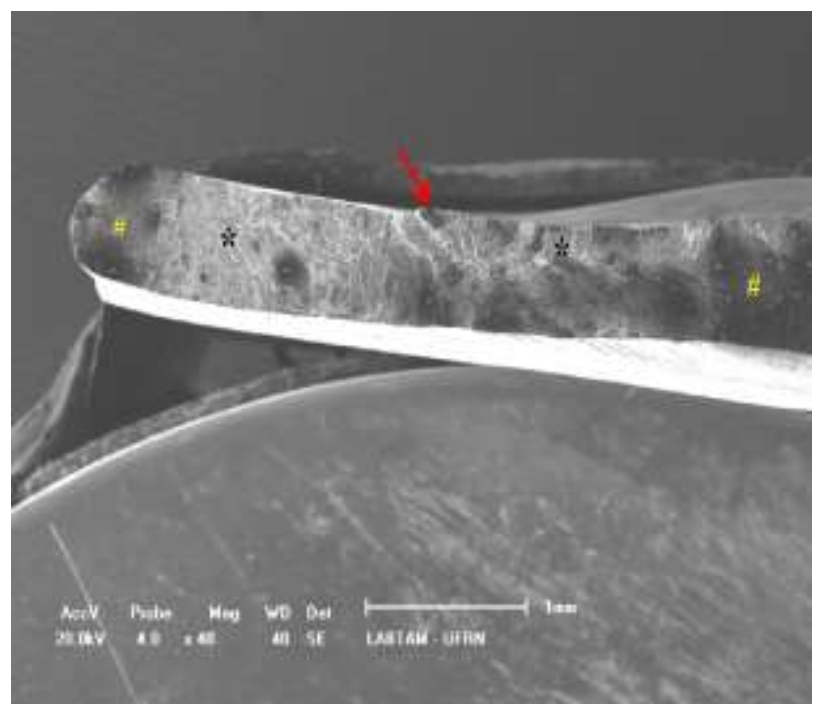

Figure 1.2- Micrographs of the fatigue fracture area: (200x).

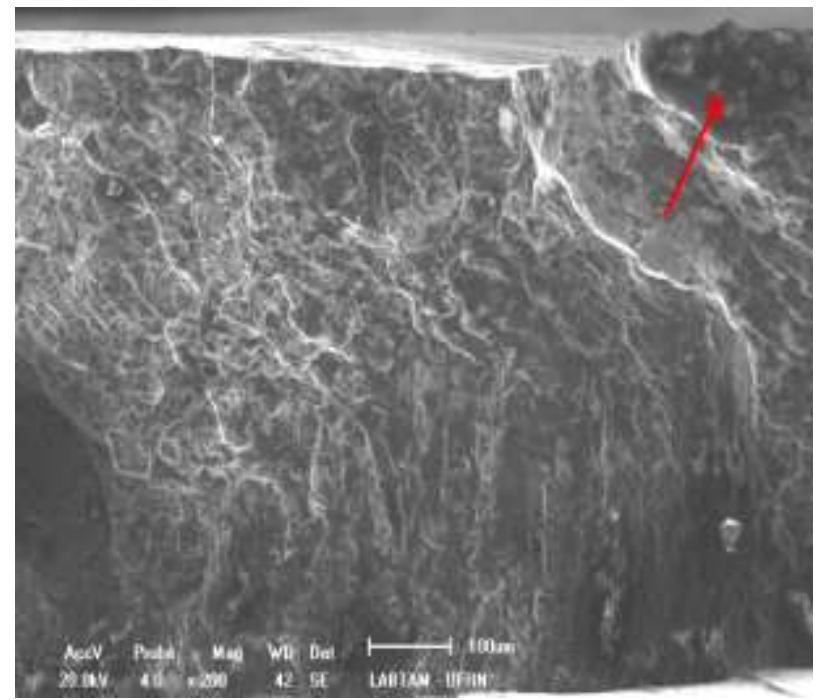


Research, Society and Development, v. 10, n. 10, e08101018370, 2021

(CC BY 4.0) | ISSN 2525-3409 | DOI: http://dx.doi.org/10.33448/rsd-v10i10.18370

Figure 1.3- Micrographs of the fatigue fracture area: (200x).

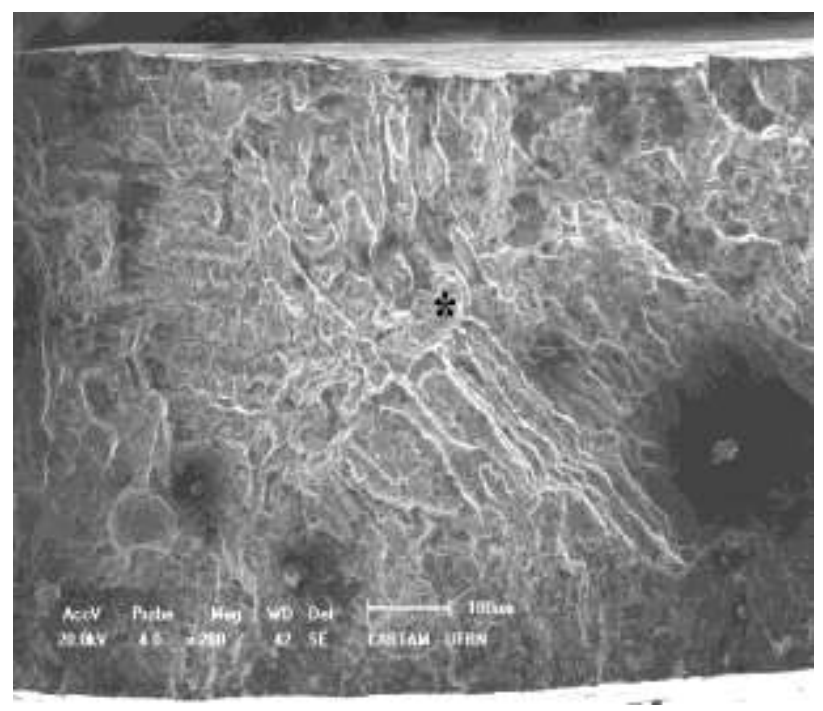

Figure 1.4- Micrographs of the fatigue fracture area: (200x).

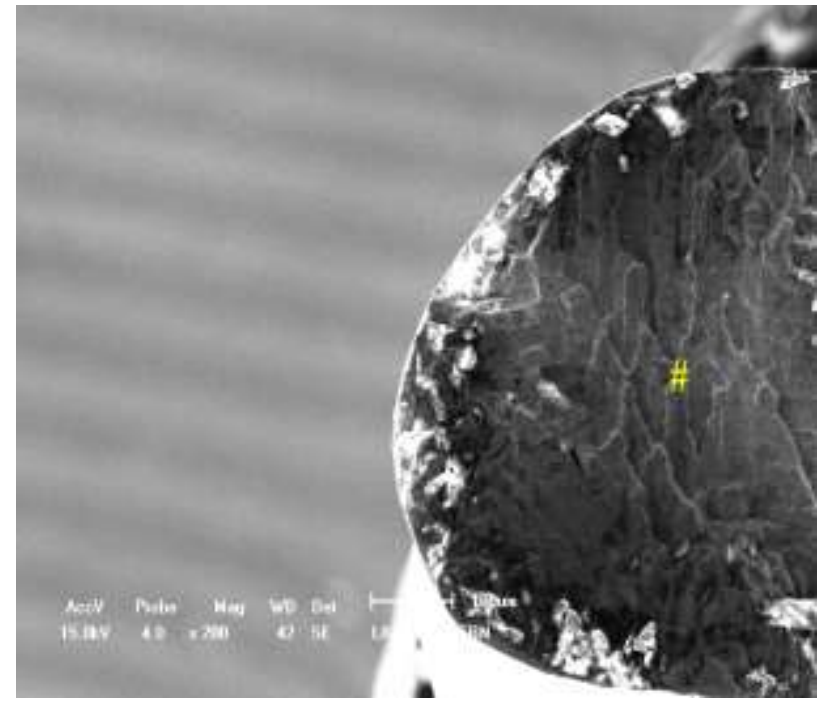

Subtitle: The red arrow indicates probable early failure.

* Indicates a ductile fracture region

\# Indicates a brittle fracture region (detachment area).

Source: Authors.

In Case A, fractographic analysis by SEM showed the fracture occurred due to fatigue (Figure 2), since the surface of the material presented 'beach marks', visible semi-elliptical lines characteristic of this type of failure.

Figure 2- Evident 'beach marks' that are characteristic of fractures caused by fatigue (1000x).

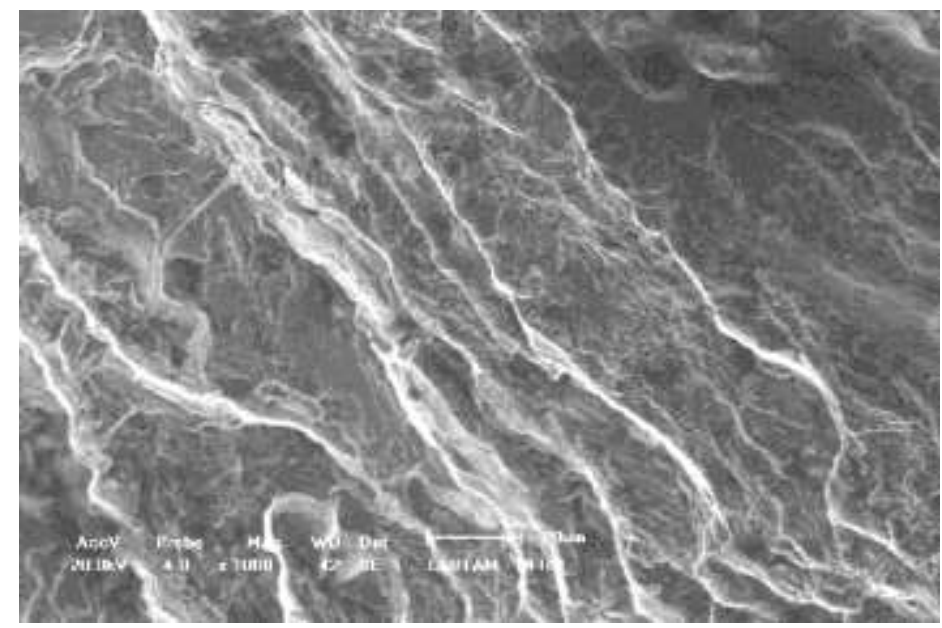

Source: Authors.

In Case B (Figure 3.1-3.3), the micrographs verified the origin of fracture and characteristics of a fragile or cleavage fracture, and the presence of an inclusion (Figure 3.1) in the center of the cross section of the larger connector. Figure 3.2 shows the mirror interface of 3.1 with a large defect in the center. 
Research, Society and Development, v. 10, n. 10, e08101018370, 2021

(CC BY 4.0) | ISSN 2525-3409 | DOI: http://dx.doi.org/10.33448/rsd-v10i10.18370

Figure 3.1- Photomicrograph of the fracture interface showing an inclusion in the center of the specimen (46x). The red arrow indicates probable early failure.

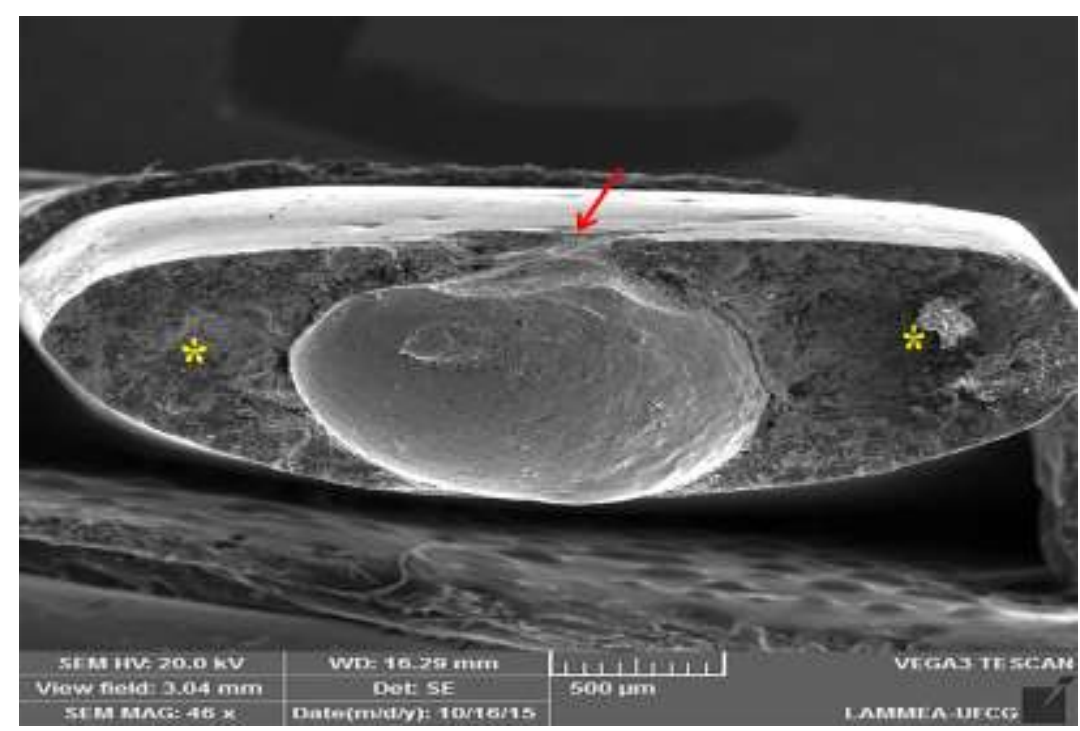

Source: Authors.

Figure 3.2- Photomicrograph of the mirror of 3.1, the fracture interface shows the void left by the inclusion (46x)

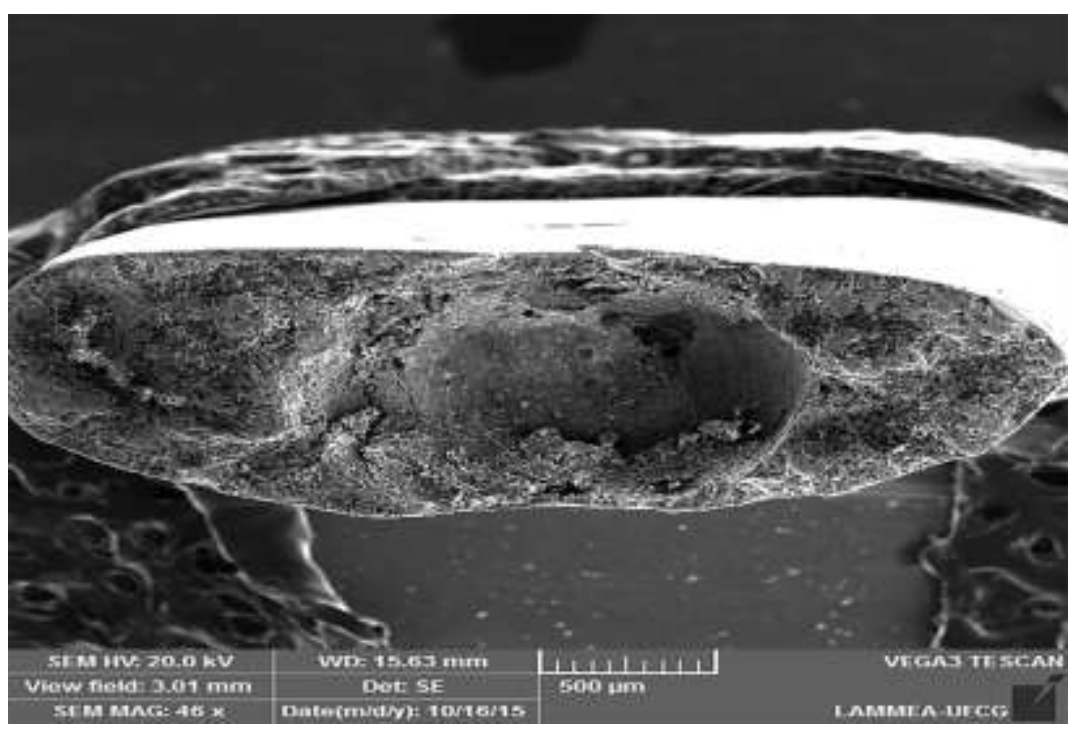

Source: Authors. 
Research, Society and Development, v. 10, n. 10, e08101018370, 2021

(CC BY 4.0) | ISSN 2525-3409 | DOI: http://dx.doi.org/10.33448/rsd-v10i10.18370

Figure 3.3- Photomicrograph showing a greater magnification of the likely beginning of the fracture, indicated by the red arrow (200x).

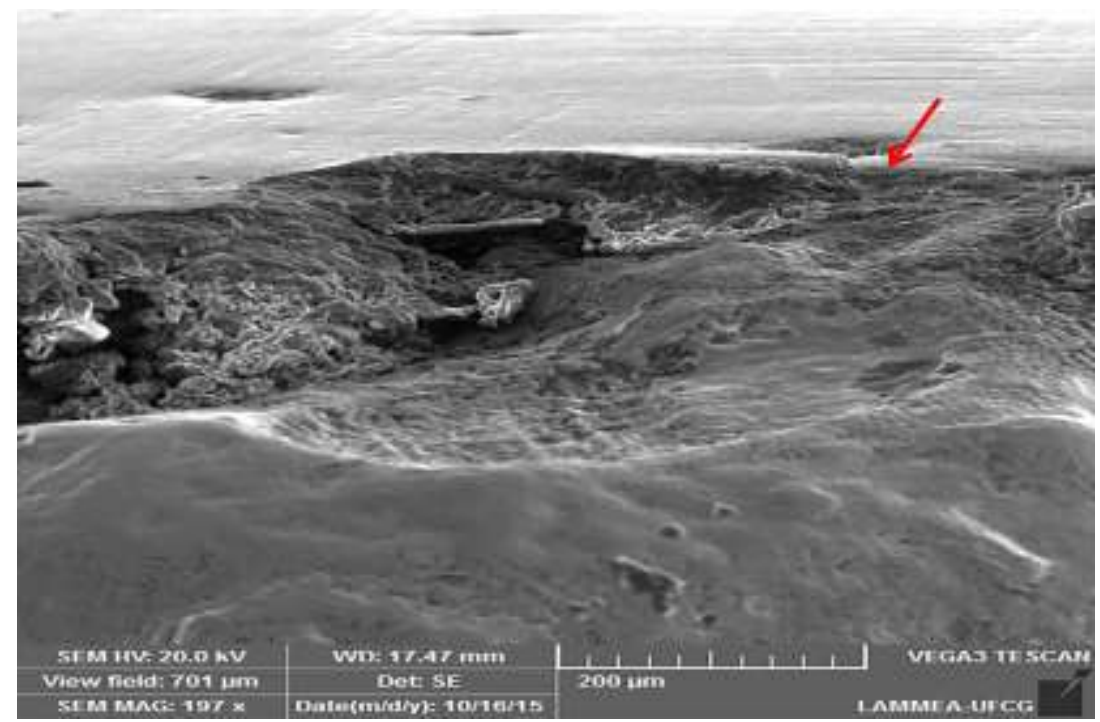

Subtitle: The red arrow indicates probable early failure.

* Shows regions that exhibit brittle fracture characteristics (detachment area).

Source: Authors.

The EDS test, performed in the specimen of case B (Figure 3.1), showed predominant and characteristic peaks for Co and $\mathrm{Cr}$ (Figure 4), with a higher concentration of chromium, but showing the same concentration of the alloy the extremities.

Figure 4- Spectroscopy (EDS) of the center of the inclusion showing characteristic peaks for $\mathrm{Cr}$ and Co, the main elements of the alloys analyzed.

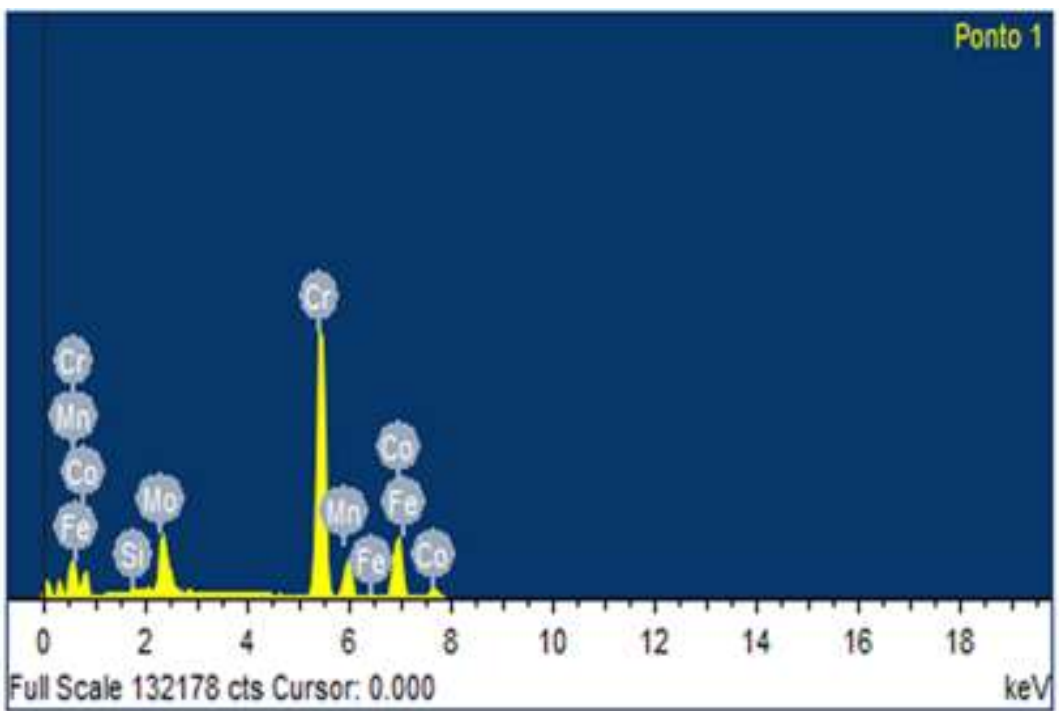

Source: Authors. 
This could account for the results presented in Case A of this study, where a mixed fracture (ductile/brittle) occurred at the junction area between major and minor connectors. Evidence for material fatigue is most clear in the 'beach marks' at the fracture interface, characteristic of this type of failure, together with the patient's continuous use of the RPD, which includes the repetitive movements of removal and insertion.

Studies on the mechanical properties of Co-Cr alloys have been published (Ghani, et al., 1990; Bridgeport, et al.,1993), but few have dealt with the fatigue of this alloy and fractographic analysis of fractured specimens (Bridgeport, et al.,1993). The limit that separates a mixed fracture (ductile/brittle) remains undefined, and only fractography is able to distinguish this type of fracture, as observed in Case A.

Although rare, connectors associated with fatigue fractures may be undersized in relation to the framework. When defining their cross section, height and width, the length of the prosthetic space, the antagonist force and the direction of the masticatory forces are usually not accounted for. The lack of studies to support such calculations means lab technicians tend to fabricate standard prostheses for cases with different structural overloads. However, the fracture of metal components of a RPD can also occur due to the casting technique used, since heating procedures, the size and arrangement of the feed channels, the temperature of the alloy and the ring fusion technique, the type of coating, etc., can influence the properties obtained, such as tensile strength, yield strength, hardness and stretching, directly affecting the clinical behavior of an RPD (Machado-Cucci, et al., 1990).

In Case B, the shape of the cross-sectional area was not sufficiently similar to that recommended by books for a lingual bar, and the micrographs showed that the fracture occurred due to possible errors during the casting process. Several hypotheses have been raised regarding the causes that led to the fracture. It seems likely that a certain amount of material was not completely fused, causing the formation of an inclusion. This may have occurred because the properties of the alloy were modified, including melting point, the alloy may have reused (Vallittu,1997), or the temperature was insufficient to complete the casting of the alloy. The last possibility could have been caused by furnace decalibration. It is also possible that the Prosthodontics technician released the alloy for injection into the feed channel before the metal was completely melted, leading to this type of defect.

It was not possible to determine the circumstances that caused the fracture in Case B, but the micrographs show an enclosed material in the metal framework, which promoted a local concentration of stress, thus reducing the mechanical properties of the framework. This type of localized defect facilitates rapid failure as soon as sufficient load is applied (Bates, 1965).

This study sought to understand the mechanisms involved in the fracture process in metallic infrastructures of RPDs, raising hypotheses to justify the cases studied. Due to the lack of studies in the literature, it is suggested that additional studies on the subject be performed so that other issues are discussed.

\section{Conclusion}

Fractography is the study and interpretation of fracture surface details and is often helpful in determining the nature of this process. Provides valuable information in analyzing a fracture, such as the modality and point of crack initiation. And to determine the cause, for example, whether due to overload or fatigue, it is necessary to carry out tests to determine auxiliary reference standards to categorize each type of failure. Fractography is an important method for diagnosing fractures in metallic infrastructures of PPRs and has proved to be efficient as an expert tool. 
Research, Society and Development, v. 10, n. 10, e08101018370, 2021

(CC BY 4.0) | ISSN 2525-3409 | DOI: http://dx.doi.org/10.33448/rsd-v10i10.18370

\section{References}

Al Jabbari Y. S. (2014). Physico-mechanical properties and prosthodontic applications of Co-Cr dental alloys: a review of the literature. J Adv Prosthod; 6: $138-45$.

Bates, J. F. (1965). Studies related to the fracture of partial dentures. Flexural fatigue of a cobalt-chromium alloy. Brit Dent J; 118 : $532-537$.

Ben-ur, Z. (1986). The fracture of cobalt-chromium alloy removable partial dentures. Quintess Int 1986; 17: $797-801$.

Blackman R, Barghi N \& Trail C. (1991). Dimensional changes in casting titanium removable partial denture frameworks. J Prosthet Dent; 65: 309-15.

Bridgeport D.A, Brantley W.A \& Herman P.F. (1993). Cobalt-chromium and nickel-chromium alloys for removable prosthodontics. Part 1: mechanical properties. J Prosthod; 2:144-50.

Carr A.B \& Brown D.T. (2011). Mc Cracken's Removable Partial Prosthodontics. 12.ed. Mosby; 400.

Craig R.G, Hanks C.T, Kohn D.H, Koran A Ill, O'Brien W.J, Peyton F.A \& et al. (1993). Restorative dental materials. 9th ed. St Louis: CV Mosby. p. $55-105,415-49$

Earnshaw R. (1961). Fatigue tests on a dental cobalt-chromium alloy. Br Dent J; 110: 341-6.

Earnshaw R. (1958). The casting shrinkage of cobalt-chromium alloys. Aust Dent; 3:159-170.

Erdle R.W \& Prange C.H U.S. patent 1956278. (1934). Apud American Dental Association. Guide to dental materials: including A.D.A. specification n. 14 for dental Co-Cr castings alloys. Chicago: A.D.A., /63; 78-88.

Ghani F \& Mahood M. (1990). A laboratory examination of the behavior of cast cobalt-chromium clasps. J Oral Rehabil; $17: 229-37$.

Harcourt H. J. (1961). Fractures of cobalt-chromium castings. Br Dent J; 110: 43-50.

Lewis A. J. (1978). Radiographic evaluation of porosities in removable partial denture castings. J Prosthet Dent; 39: $278-281$.

Machado-Cucci A. L, Fuller J. B, Giampaolo E. T \& Leonardi P. (1990). Fatigue of retentive clasps of removable partial dentures. Effect of alloys, thickness and casting techniques. 2. Rev Odontol Unesp; 19: 251-8.

Morris H. F, Farah J. W, Craig R.G \& Hood J. A. (1976). Stress distribution within circumferential clasp arms. J Oral Rehabil; 3: $387-94$.

Noort R. V \& Lamb D. J. (1984). A scanning electron microscope study of Co-Cr partial dentures fractured in service. J Dent; 12 : $122-6$.

Paffenbarger G. C, Caul D. J \& Dickson G. (1943). Base metal alloys for oral restorations. J Am Dent Ass; 30: $852-862$.

Pang Z, Chughtai A, Sailer I \& Zhang Y. (2015). A fractographic study of clinically retrieved zirconia-ceramic and metal-ceramic fixed dental prostheses. Dent Mater; 31: 1198-206.

Phillips R. W. (1991). Skinner's science of dental materials. 9 ed. Philadelphia: WB Saunders Co. p. 40.

Vallittu P.K. (1997). Transverse strength, ductility, and qualitative elemental analysis of cobalt chromium alloy after various durations of induction melting. J Prosthodont.; 6:55-60.

Wouters R \& Froyen L. (1997). Materials characterization. Elsevier Science Inc; 25-41 